\title{
Análise semiótica de capas de livros didáticos
}

\author{
Semiotic analysis covers textbooks \\ El análisis semiótica de las capas de libros didácticos \\ Luciana Vieiral \\ Almerinda Tereza Bianca Bez Batti Dias ${ }^{2}$ \\ http://dx.doi.org/10.5216/32076
}

\begin{abstract}
Resumo
À luz dos estudos semióticos de Charles Sanders Peirce, mais exatamente as três categorias universais primeiridade, secundidade e terceiridade - esta pesquisa tem como objetivo analisar as três capas do livro: Português Linguagens, respectivamente dos primeiro, segundo e terceiro anos do ensino médio a fim de comprovar que é possível usar as categorias peirceanas para interpretar imagens, neste estudo, as capas de livros didáticos. A abordagem utilizada nesta pesquisa foi qualitativa, à luz do paradigma interpretativista, usando a Semiótica Peirceana como ciência e como método de pesquisa. Ao realizar a investigação, percebemos que, em cada uma das categorias universais de Peirce, é possível interpretar as imagens dos livros didáticos.
\end{abstract}

Palavras-chave: Semiótica Peirceana. Categorias Peirceanas. Pesquisa Qualitativa.

\begin{abstract}
Under the light of Charles Sanders Peirce's semiotic studies, more exactly his three universal categories - firstness, secondness, thirdness - this research aims to analyze three book covers: Português Linguagens, respectively the first, second and third years of high school to demonstrate that it is possible to use the Peirce an categories to interpret images, in this case, the covers of textbooks. The approach used in this research was qualitative, using the Peircean Semiotics as a research method. When conducting research, we realized that, in each of Peirce's universal categories, it is possible to interpret the images the covers of textbooks.
\end{abstract}

Keywords: Peircean Semiotics. Pericean Categories. Research Qualitative.

\section{Resumen}

A la luz de los estudios semióticos de Charles Sanders Peirce, más precisamente las tres categorías universales - primeridad, alteridad y terciedad - esta investigación tiene como objetivo analizar las tres portadas de libros del portugués, respectivamente el primero, segundo y tercer año de la escuela secundaria para demostrar que es posible utilizar las categorías de Peirce para interpretar las imágenes, en este estudio, las capas de los libros didácticos. El enfoque utilizado en esta investigación fue cualitativa a la luz del paradigma interpretativo, usando la Semiótica de Peirce como ciencia y como método de investigación. Al llevar a cabo la investigación, nos dimos cuenta de que cada una de las categorías universales de Peirce es posible interpretar las imágenes de los libros de texto.

Palabras-clave: Semiótica Perciana. Categorías Peirceanas. Investigación Cualitativa.

\footnotetext{
${ }^{1}$ Graduada em Letras pela Universidade do Extremo Sul Catarinense (UNESC). Brasil, Santa Catarina, Criciúma. E-mail: lucianavieira42@yahoo.co.br

${ }^{2}$ Mestra em Ciências da Linguagem e Doutora em Administração. Professora na Universidade do Extremo Sul Catarinense (UNESC). Brasil, Santa Catarina, Criciúma. E-mail: bianca@unesc.net
}

Comun. \& Inf., Goiânia, GO, v. 17, n. 2, p. 38-54, jul./dez. 2014 


\section{INTRODUÇÃO}

Semiótica é uma área de estudos antiga, começando com os gregos, como Platão e
Aristóteles, surgindo também na Idade Média, com Santo Agostinho, Roger Bacon,
São Tomás. Durante os séculos XVII e XVIII, destacou-se com os estudos filosóficos de John Locke em sua doutrina dos signos e Johann H. Lambert, em seu tratado intitulado Semiotik esclareceram Nicolau et al. (2010) e Merrel (2012).

Charles Sanders Peirce (1839-1914), considerado um dos pais da Semiótica moderna, foi um cientista eclético (matemático, físico, químico, filosófico, psicológico), seu pai, Benjamim Peirce, foi, em sua época, o mais importante matemático de Harvard e sua residência um ponto de convergência dos eruditos e cientistas da época. Essa situação, possivelmente, influenciou Peirce desde criança, e sua precocidade fica evidente quando escreve aos onze anos uma História da Química. Tempos depois na disciplina de Química bacharelou-se na Universidade de Harvard.

Entre as atividades de Pierce, segundo Santaella (2000), destacam-se também os estudos da matemática, física, astronomia na área das ciências exatas e naturais, entretanto, em nenhum momento de sua vida, Pierce enfatizou estritamente às ciências exatas e naturais. No campo das ciências sociais, ele se dedicou particularmente à Linguística, Filologia e História. Isso sem mencionarmos as enormes contribuições à Psicologia que fizeram dele o primeiro psicólogo experimental dos EUA.

O seu eclético conhecimento das ciências era uma maneira de ele dedicar-se ao estudo da Lógica. A Lógica das ciências era para ele um modo de entender em primeiro lugar seus métodos de raciocínios. Pierce procurava sempre estabelecer categorias universais, de maneira que todas as ciências pudessem ser explicadas à luz desse raciocínio, os fenômenos pesquisados.

Atualmente, há um grande interesse na interpretação das diversas formas de materialização da linguagem. A Semiótica passa, então, a ser importante "ferramenta" para atender essa demanda. Embora a Semiótica proposta por Peirce, como lógica não seja uma ciência aplicada, pois se trata de uma proposta de categorias universais, ela tem sido aplicada como método em diversas áreas de estudo. Simões (2004, p, 35) ratificou ao dizer que "[...] cremos que examinar algo numa perspectiva Semiótica consiste em reeducar-se a percepção do mundo; redirecionar a capacidade de captação dos signos e significações resultantes da interação do homem com seu mundo e com o mundo que o cerca." Além disso, os autores Morris (1976), Carontini e Peraya (1979), Fidalgo (1998) e Santaella (1989, 2000, 2002, 2006) 
argumentaram que a Semiótica tanto é ciência como pode ser método de pesquisa de outras ciências.

Diante desse contexto, tem-se como questão de pesquisa: como usar as categorias peirceanas para interpretar imagens das capas de livros didáticos? E, com a finalidade de esclarecer a questão acima, é necessário analisar, à luz da Semiótica Peirceana, mais precisamente as três categorias fenomenológicas como método de análise, as três capas do livro didático Português Linguagens da editora Saraiva.

\section{SIGNO}

Com a crescente proliferação de signos, fica evidente a necessidade de que o homem entenda profundamente o signo com o qual ele está familiarizado em seu dia-a-dia. Para Eco, precisamos nos desvincular do conceito primitivo do signo e entender que as noções de signo são muito mais amplas e discutíveis do que podemos imaginar. Eco defendeu que "a noção de signo adquire significados frequentemente não homogêneos" (ECO, 1991, p. 8) Peirce definiu signo (ou representamen): "Qualquer coisa que conduz alguma outra coisa (seu interpretante) a referir-se a um objeto ao qual ela mesma se refere (seu objeto), de modo idêntico, transformando-se o interpretante, por sua vez, em signo, e assim sucessivamente ad infinitum". (PEIRCE, 2000, p. 74).

Santaella postulou que tudo depende dos signos, nossa vida gira em torno dos signos, sem eles não seria possível a interação e a compreensão entre os homens. Segundo a autora, vivemos em um mundo cada vez mais evoluído e complexo, e os signos proliferam constantemente. Partindo desse pressuposto, surge então a necessidade de compreendê-los. Nesse exercício de entendimento, Santaella (2000) sugeriu primeiramente nos desvincularmos do conceito de que a noção de signo equipara-se apenas ao signo verbal.

Para Morris (1976) e Santaella (2000), signo pode ser definido como "qualquer coisa" ou "alguma coisa que". A palavra "coisa" não deve restringir apenas a ideia de objeto real, ou seja, não é essencialmente alguma coisa concreta, pode ser naturalmente uma "ideia" ou “abstração". Walther-Bense (2000) considerou que o signo está por toda parte auxiliando os homens na interação uns com os outros por meio da comunicação, da representação, da sensação física que podem ser nossos sentimentos, desejos, sonhos, entre outros. A autora descreveu ainda que não existe um signo apenas pensado ou sozinho, isto é, não podemos desvincular o signo de sua interpretação, pois um signo é justificado por outros signos. 
Segundo Morris (1976), os signos “designatum”, intérprete ou interpretante, envolvemse uns aos outros e são atributos relacionados ao processo funcional da semiose. Para ele, a caracterização de um signo precisa da interação entre os processos relacionados, ou seja, alguma coisa será considerada um signo a partir de uma interpretação, e essa interpretação será proveniente de um objeto que explica alguma coisa. A Figura 1 a seguir ilustra o triângulo semiótico.

Figura 1 - Triângulo semiótico.

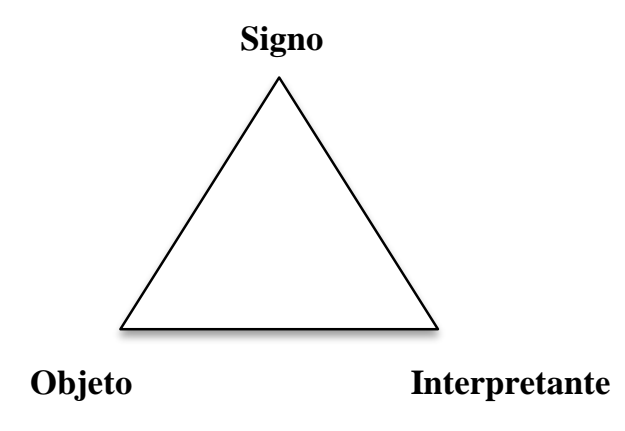

Fonte: Pignatari (2004, p. 48, adaptado).

Walther (2000) pressupõe que o signo pode ser considerado como uma relação triádica, e que cada signo desempenha um sistema de referência que nos permite analisar separadamente.

\section{CATEGORIAS SEMIÓTICAS}

Peirce buscava, em sua teoria, a divisão dos signos em três categorias: Primeiridade, Secundidade e Terceiridade, as quais seriam categorias fenomenológicas universais a fim de possibilitar o estudo de fenômenos diversos por intermédio de concepções simples e universais.

Santaella $(1983 ; 2010)$ esclareceu que a Primeiridade é o presente imediato, ou seja, tudo que está na consciência de alguém no instante presente. Ela descreveu que (primeiridade) o presente é original, novo, espontâneo e livre, e que não pode ser articulado e pensado porque, se parássemos para pensar o presente, tornar-se-ia passado. Explica ainda que, em nossa consciência, as qualidades de sentimentos estão permanentemente gravadas, ainda que imperceptíveis. Tais qualidades são partes integrantes do pensamento e das sensações do presente imediato em nossa consciência. Martins, Simões e Freitas (2011) ratificaram: na primeira categoria (primeiridade), trata-se do imediato e do presente, uma qualidade, quer dizer, nossa consciência ao observar algo não faz análise, comparações, imaginações com qualquer outro coisa. 
Na secundidade, Santaella $(2002 ; 2010)$ expôs que se refere à emoção, reação que sentimos ao analisar algo. Ao observar qualquer coisa pequena ou grande, corriqueira ou não, nossos sentidos estimulam reações exteriores que produzem efeito em nós. Essas reações geram conflitos entre esforço e resistência, buscando entender o fenômeno considerado. Quanto à secundidade, Simões (2001) e Martins, Simões e Freitas (2011) argumentaram que esta categoria remete à ideia de reação e que Peirce referiu-se a ela como o "ensinamento da experiência". Esta experiência possui componentes como conflitos, limitações, resistências que adquirimos ao longo de nossa vida e que são característicos das reações que temos diante do objeto observado.

Relativo à terceiridade, Santaella $(1983 ; 2001)$ postulou que, para compreendermos algum fenômeno, nossa consciência processa um signo, um entendimento entre nós e o fenômeno, assim, esse processo é a mediação entre o objeto que se quer conhecer e a nossa consciência. Santaella descreveu ainda que o homem apenas conhece, compreende e interpreta um signo por meio de outro signo. Martins, Simões e Freitas (2011) complementaram ao dizer que a terceiridade é a categoria da mediação, a qual relaciona coisas entre si. Essa associação tende a formar hábitos, representações que posteriormente configurarão leis.

Walther-Bense (2000) esclareceu que cada uma das três categorias universais de Peirce tem sua representação: a primeiridade representa o meio e refere-se às qualidades de sensação, são independentes e desvinculadas de qualquer ligação ou lembrança; a secundidade representa o objeto e diz respeito às experiências que são dependentes do espaço e do tempo, ou seja, por meio das experiências adquiridas temos a percepção da realidade em que interagimos; e a terceiridade representa o interpretante. Em se tratando ainda das categorias triádicas, Martins, Simões e Freitas (2011, p. 42) argumentaram que as referências triádicas "se apresentam a nossa consciência diante dos fatos em diferentes níveis do pensamento".

Nicolau et al. (2010) esclareceram que o mundo em nossa volta é reconhecido e interpretado a partir das relações triádicas em nossa mente. As coisas do mundo, reais ou não, inicialmente nos surgem em nossa memória como uma qualidade - primeiridade -, em seguida estabelecemos um vínculo com alguma coisa que já conhecemos, isto é, secundidade e, por fím, trata-se da terceiridade como interpretação, em que a mente consegue esclarecer o que assimilamos. Merrell (2012) sintetizou no mesmo sentido: primieridade é a qualidade, possibilidade; secundidade é efeito, atualidadade; terceridade é processo, é potencialidade ou necessidade.

De acordo com Santaella, Peirce dedicou atenção especial a três tricotomias, que por

Comun. \& Inf., Goiânia, GO, v. 17, n. 2, p. 38-54, jul./dez. 2014 
sua vez foram as mais conhecidas e mais difundidas. A elas, Peirce afirmou que "suas três categorias eram a pedra preciosa que ele deixava para a história da filosofia" (SANTAELLA, 2010, p. 107). Primeiramente Peirce analisou a relação do signo consigo mesmo (quali-signo, sin-signo e legi-signo), a conexão do signo com o objeto dinâmico (ícone, índice e símbolo) e a relação entre signo com o seu interpretante (rema, dicente e argumento), conforme ilustra a figura a seguir.

Figura 2 - Tricotomias e suas relações.

\begin{tabular}{|c|c|c|c|}
\hline $\begin{array}{c}\text { Categorias/ } \\
\text { Tricotomias }\end{array}$ & $\begin{array}{c}\text { Signo 1 } \\
\text { em si } \\
\text { mesmo }\end{array}$ & $\begin{array}{c}\text { Signo 2 } \\
\text { com seu } \\
\text { objeto }\end{array}$ & $\begin{array}{c}\text { Signo 3 } \\
\text { com seu } \\
\text { interpretante }\end{array}$ \\
\hline Primeiridade & quali-signo & ícone & Rema \\
\hline Secundidade & sin-signo & índice & Dicente \\
\hline Terceiridade & legi-signo & símbolo & Argumento \\
\hline
\end{tabular}

Fonte: Santaella, 1983.

Para entendermos como funcionam as subdivisões do signo, Santaella (2000) afirmou que todas as tricotomias instituídas por Peirce não funcionam como classes separadas, mas de forma organizada e unida, ou seja, nenhum signo pertence unicamente a um determinado tipo dentro das categorias triádicas.

\section{TRICOTOMIAS DO SIGNO}

Primeiramente, vejamos as relações do signo com ele mesmo: quali-signo, sin-signo e ligi-signo. No quali-signo, propriedade da primeiridade; para Peirce, esta primeira subdivisão (quali-signo) é um signo que funciona como qualidade. No entanto, a qualidade precisa estar incorporada em um objeto para que ela seja denominada signo. Quanto ao sin-signo, propriedade da secundidade, Peirce se referiu a uma ideia de singular, individual e objeto da experiência direta, com o qual relacionamos qualquer coisa com aquilo que conhecemos. $\mathrm{Na}$ opinião de Epstein (1991) e Netto (2003), o sin-signo é algo ou acontecimento existente que é tomado como signo. Para os autores o prefixo sin pretende indicar a ideia de único, singular. Um sin-signo implica vários quali-signos quando eles são efetivamente materializados.

Por último, o legi-signo, propriedade da terceiridade, é uma lei instituída por uma convenção ou acordo coletivo. Para Santaella (2000), ele é por natureza um signo, sendo decodificado ou não. Na última subdivisão do signo, o legi-signo, Peirce falou que é uma lei que é um signo. Não se trata de um objeto singular, mas mantém sua identidade em todas as suas representações.

A segunda tricotomia trata da relação existente entre signo e seu referente (objeto). O

Comun. \& Inf., Goiânia, GO, v. 17, n. 2, p. 38-54, jul./dez. 2014 
ícone - primeiridade - só será um signo se existir uma similaridade entre signo e o objeto representado, ainda que este objeto não exista. Além do mais, Santaella (2000) argumentou que os ícones são capazes de produzir em nossa mente situações de semelhança entre signo e objeto. Nas palavras de Peirce (2000, p. 52), o ícone “[...] é um signo que se refere ao objeto que denota apenas em virtude de seus caracteres próprios.” Epstein (1991) e Netto (2003) descreveram ícone como sendo um signo que possui similaridades com o seu referido objeto, ou seja, é a representação mais fiel de uma determinada coisa, sendo o signo mais fácil de identificar, pois os aspectos comuns existentes entre o signo e o objeto indicam uma qualidade ou propriedade logo percebida.

Para que o índice - secundidade - desempenha-se como signo, necessita da relação de similaridade entre signo e objeto. Santaella (2000) esclareceu que o signo necessita do interprete, mas não será o interprete que atribuirá poder, pois a capacidade do índice vem inteiramente da ligação com seu objeto, ou seja, o índice perderia sua característica, que faz dele um signo, se não houvesse o seu objeto, característica esta que independe do interpretante. No entender de Netto (2003), o índice é um signo que tem característica em comum com o objeto. No entanto, não são essas características que o torna um signo, mas o fato de ser transformado pelo objeto.

A terceira tricotomia se refere à relação do signo com seu interpretante, em que Rema consiste nas possibilidades interpretativas do signo por seu interpretante final. $O$ objeto possuidor de qualidades dará ao interpretante possíveis informações de "algo" existente, a fim de nos despertar emoções, não nos levando a decisões. Epstein (1991) esclareceu que o rema não nos habilita a ter uma decisão formada, convicta. Ele nos capacita para termos um ponto de vista, um conceito de uma determinada coisa, e que naturalmente tais conceitos não são verdadeiros e nem falsos.

Discente é um signo meramente referencial, pois mediante as afirmações de seu interpretante final é possível ter informações sobre determinada coisa, e se ela é verdadeira ou falsa e o porquê do resultado. Netto (2003) argumentou que um discente é um signo de fato, ou seja, um signo que tem a existência concreta, de verdade. $\mathrm{O}$ argumento é um signo interpretado pelo interpretante final por meio de uma lei, uma regra. Conforme Santaella [3], Peirce afirmou que um argumento precisa ser entendido por seu interpretante, pois ele fornecerá conclusões que tende a ser verdadeiras. Walther-Bense (2000, p. 25) complementou dizendo que o argumento "[...] representa uma conexão de signos completa, regular e é considerado logicamente, necessariamente verdadeiro, ou 'sempre verdadeiro'.” Para Netto (2003), um 
argumento é um signo de lei, de razão. O autor apontou que o silogismo é um exemplo de argumento (“A é B, B é C, portanto A é C”).

\section{MÉTODO}

Trata-se de pesquisa qualitativa, utilizando a análise semiótica peirceana, além de ciência, como método de pesquisa. Neste trabalho, temos como corpus da pesquisa as três capas dos livros do $1^{\circ}, 2^{\circ}$ e $3^{\circ}$ anos do Ensino Médio da coleção Português Linguagens, indicada pelo MEC - Ministério da Educação no Programa Nacional do Livro Didático - os quais foram escolhidos por conveniência, ou seja, disponibilidade de acesso aos livros pela pesquisadora.

O Programa Nacional do Livro Didático (PNLD) tem a finalidade de avaliar as coleções das obras existentes no mercado. Essa avaliação é importante, pois auxilia os professores das redes federal, estadual e municipal a escolherem livros didáticos de qualidade. Após a avaliação dos livros, o MEC publica uma resenha descrevendo as obras consideradas aprovadas para o ensino da língua portuguesa em sala de aula.

A análise Semiótica das três capas se deu pelas três categorias na seguinte ordem: primeiridade, secundidadee terceiridade. Na primeira categoria, buscamos perceber a consciência tal como ela é em determinado momento, é a consciência imediata, corresponde ao acaso, à variação espontânea, é o sentir puro. Na secundidade, é a consciência reagindo em relação a uma realidade cotidiana, é a ação e reação a fatos concretos, é a materialização da qualidade, trata-se da ação e reação aos fatos concretos. Por fim, na terceiridade, é a consciência reagindo em relação a uma realidade cotidiana, é a ação e reação a fatos concretos, é a materialização da qualidade, trata-se da ação e reação aos fatos concretos.

Dias (2013), em seu ensaio teórico, propôs um procedimento de análise de textos verbais e não verbais a partir das três categorias de Peirce adotadas nesse trabalho (Quadro 1).

Quadro 1 - Procedimentos de análise semiótica

\begin{tabular}{|l|l|}
\hline \multicolumn{1}{|c|}{ Categorias } & \multicolumn{1}{c|}{ Procedimentos de análise } \\
\hline Primeiridade & $\begin{array}{l}\text { Trata-se do primeiro contato com o texto verbal e ou não-verbal. A } \\
\text { primeira percepção do interpretante com relação ao signo, sem fazer } \\
\text { nenhum vínculo dele com seu objeto. O leitor deverá ter a sua "primeira } \\
\text { impressão", uma abstração. }\end{array}$ \\
\hline Secundidade & $\begin{array}{l}\text { É a reação do interpretante frente à percepção da qualidade já a } \\
\text { relacionando. O leitor fará a inter-relação e integração com seu objeto. }\end{array}$ \\
\hline
\end{tabular}


Terceiridade

Dar-se-á o significado ao signo conforme a sua inter-relação com o seu objeto.

Fonte: Dias (2013 com base em SANTAELLA, 2002 e MERRELL, 2012)

\section{ANÁLISE SEMIÓTICA}

$\mathrm{Na}$ análise da primeira capa, apresentaremos, além da análise por categoria como previsto no método, os elementos que compõem a relação do signo com ele mesmo, com o objeto e com o interpretante. Para as demais capas, a fim de não ficar repetitivo, a análise será apresentada considerando apenas as três categorias universais.

A primeira imagem a ser descrita (Figura 3) faz referência à capa de livro didático do ensino médio1. Nela encontramos algumas imagens como: um celular iphone3G, uma figura de uma mulher trajando vestimenta nada usual nos dias atuais e o desenho de um gato preto. A cor de fundo com tonalidade em laranja destaca as figuras que estão praticamente em preto e amarelo. $\mathrm{O}$ título e os nomes dos autores vêm em destaque em amarelo e branco em cima de um quadro negro. Conforme ilustra a Figura 4 a seguir.

Figura 3 - Capa livro didático $1^{\circ}$ ano

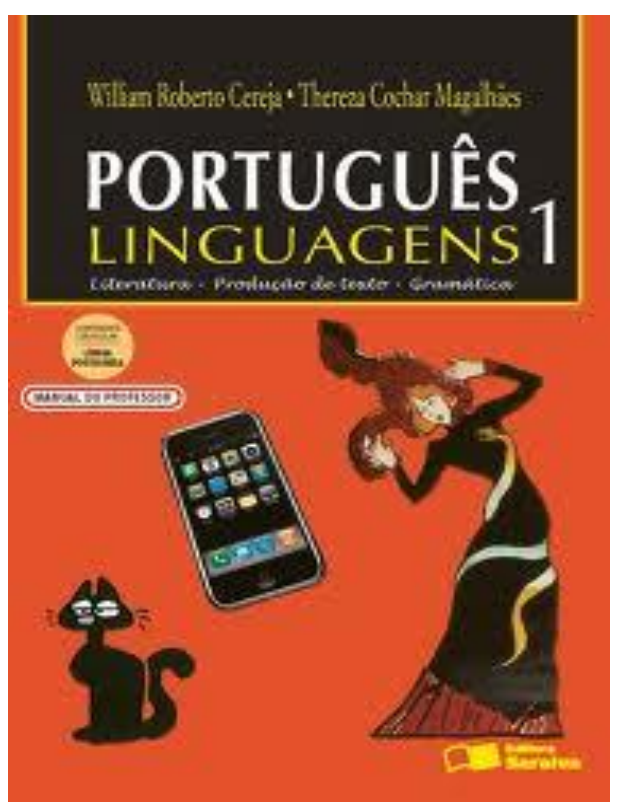

Fonte: CEREJA, $2008^{\mathrm{a}}$.

Considerando a teoria Peirceana, cada imagem contida na capa do livro é um signo que representa um objeto específico. Ao analisar as imagens contidas na capa do livro didático em estudo como fenômeno no contexto das categorias de Peirce, deve-se entender que, na primeiridade, acontecem as espontaneidades sem comparações ou imaginações com qualquer outra coisa. Trata-se das qualidades, sensações do presente imediato, é a relação do signo com ele mesmo - quali-signo esclareceram Peirce (2000), Waler-Bense (2000), Simões (2001), 
Santaella $(2002,2010)$ e Merrel (2012). O interpretante capta apenas o que é relevante para a sua análise emergente. Partindo desse pressuposto, o que nos apresenta a capa, no primeiro momento, são imagens muito rapidamente percebidas, assim sendo, a figura de um celular iphone $3 \mathrm{G}$ nos remete a algo moderno, usado nos dias atuais o qual contrasta com a gravura da mulher com vestimenta que nos remete ao passado. Essa relação se dá em função das qualidades trazidas pelos signos em sua relação com ele mesmo, e com a relação com seu objeto, ou seja, as imagens apresentadas na capa se assemelham aos seus objetos, no caso da imagem do celular com o próprio aparelho. Essas semelhanças, na relação do signo com seu interpretante -rema, ainda na primeiridade, trará somente a informação que, para o interpretante, é essencial, neste caso foi o objeto atual com a figura do passado.

Na secundidade, estabelece-se uma relação que é marcada pela reação diante do que a consciência imediata percebe defendeu Peirce (2000). Essas reações geram conflitos entre esforço e resistência que estimulam o reconhecimento dos elementos da realidade externa. Essa segunda categoria dos estudos de Peirce permite-nos fazer uma nova análise, mais ampla, da imagem, por exemplo, o celular que aparece na capa do livro é um telefone moderno, com vários aparatos tecnológicos, bonito, o aparelho perfeito para auxiliar-nos em várias situações no nosso dia-a-dia independente da vontade do interpretante - sin-signo. É inegável que o celular, como índice, tornou-se a figura da comunicação dos tempos atuais, algo necessário para as pessoas de modo geral. Ao vê-lo, já temos, em nossas mente, a ideia de comunicação, já que, com ele, é possível não só falar, com qualquer pessoa, seja familiar, amigos ou profissional, mas também mandar mensagens, tirar foto, conectar na internet, ouvir música, filmar por meio do celular, este é o retrato da evolução tecnológica - discente.

Quanto às figuras da mulher e do gato -sin-signo, elas nos remetem a personagens literários do passado - índice. A caricatura da mulher que traz a imagem da dançaria de CanCan francesa, Jane Avril, (1868-1943), representada pelo pintor Toulouse-Lautrec em inúmeros cartazes e pinturas, já o gato preto é personagem do quadrinista Laerte. Por meio do teatro, poema e conto, a literatura estabelece um caráter comunicativo, porque envolve pessoas: umas assistindo/ouvindo; outras declamando. Em vista disso a linguagem literária promove significativamente a construção de conhecimento e socialização entre as pessoas - discente. Essas linguagens artísticas caracterizam-se como meio de comunicação desde suas origens, desempenhando diferentes papéis na sociedade através dos tempos. Na reação da consciência, percebemos que se trata de um passado no teatro, na arte que são atemporais, ou seja, permanecem até os dias de hoje. 
No âmbito da terceiridade, segundo a teoria, existe uma mediação interpretativa entre a consciência e o objeto analisado. Esse processo de mediação necessita da junção da primeiridade e da secundidade para que o interpretante compreenda e interprete o fenômeno avaliado. A imagem do aparelho telefônico, moderno e com diversas funções, estabelece uma associação convencional com a palavra celular, mostrando-se como um símbolo visual, linguístico intitulado pelo homem, esse conceito mental - legi-signo - de comunicação faz parte da natureza humana atualmente, que passa a ter consenso - símbolo - entre as pessoas as quais ao verem a imagem do iphone 3G imediatamente relacionam-no à modernidade, produzindo inúmeros significados: agilidade, tecnologia, comunicação, entre outros - argumento.

O mesmo ocorre com a imagem da mulher. O conceito mental que temos é de algo do passado, antigo - legi-signo -, mas atual. A vestimenta é um símbolo que nos remete ao hábito de sua época e que, em principio, todos terão essa leitura por se tratar de um consenso, no mínimo, de que a imagem da mulher não é da atualidade. Todos os significados que vamos construindo - argumentos - remete-nos a um passado de arte. Portanto, podemos considerar que o retrato explícito das imagens, na capa analisada, pretende estabelecer conexão entre a comunicação literária (passado), que jamais fica datada, com os novos meios de comunicação existentes nos dias atuais. Trata-se da comunicação atemporal.

Ao olharmos as representações contidas na capa do livro didático (Figura 4), percebemos a caricatura de um homem sentado em um banco de praça com um livro e uma pena na mão, um rolo de filme cinematográfico, um poste antigo de iluminação de praça e por fim um desenho de uma boneca matando um mosquito. À primeira visão é de passado e atualidade, expressas pela caricatura do homem no banco, a iluminação em contraste com a personagem de cartoon. É visível, portanto, o contraste entre o atual, representado pelo cartoon, e o passado, expresso pelo banco da praça, pela pena e pela luminária, época em que não havia iluminação elétrica. A semelhança da caricatura com o eterno Carlos Drummond de Andrade e suas poesias, o rolo de filme com o cinema, ferramenta importante no processo de comunicação entre as pessoas, é algo do passado, mas também pertinente ao presente.

Figura 4 - Capa livro didático $2^{\circ}$ ano. 


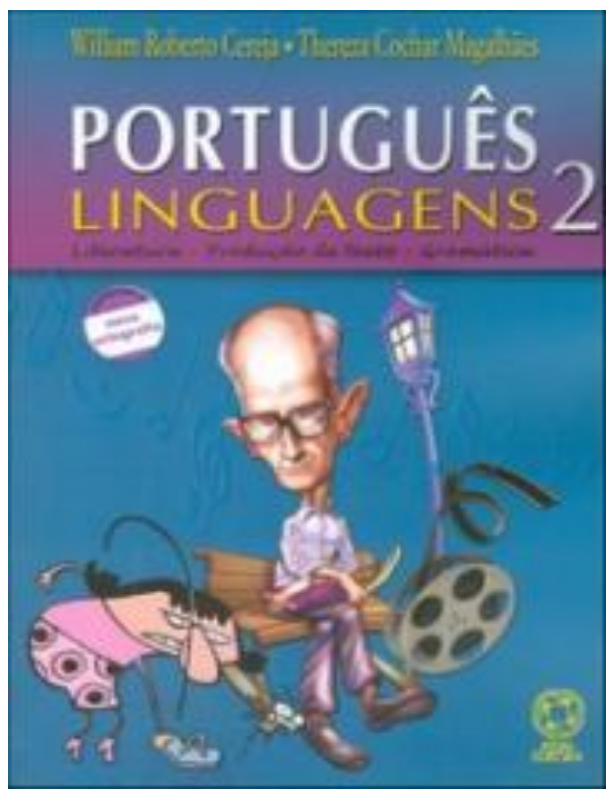

Fonte: CEREJA, 2008b.

Em relação à segunda categoria de Peirce, ao analisarmos a segunda capa, a caricatura faz com que passemos a perceber a realidade, e ela deixa de ser um desenho para remeter-nos, evidentemente para quem tem esse conhecimento de mundo, ao poeta Carlos Drumond de Andrade - sereno, observador e pensante, sentado em branco simples de madeira, típico da época. Este artista foi um importante escritor da literatura brasileira do século XX. Suas obras constituem parte importante do acervo cultural brasileiro, contribuição riquíssima para a linguagem e sua comunicação com as pessoas e entre as pessoas.

A expressão da boneca (na Figura 4) não nos revela felicidade, e sim irritação com o inseto, tentando até mesmo matá-lo. O cartoon também é uma forma de comunicação antiga, mas bastante usada na atualidade, por meio dos desenhos, das histórias em quadrinho, o diálogo é estabelecido desde as cores usadas, o formato do desenho, as expressões, até a fala de seus personagens. É a nossa consciência reagindo, buscando vínculo entre o signo e o objeto.

Considerando a categoria da terceiridade, ao analisarmos o retrato da menina, nossa mente relaciona com o desenho animado, colorido, a juventude; a caricatura serena de Carlos Drumond de Andrade nos remete a um escritor famoso e importante para a literatura brasileira; o desenho do rolo de filme cinematográfico nos transmite imaginação, diversão, felicidade e, também, tristeza. Enfim a relação entre a literatura e o cinema é muito próxima no sentido de que ambos utilizam a linguagem para contar histórias/e estórias, revelam atitudes irrelevantes à sociedade. Nesta categoria, juntamos a primeiridade e a secundidade para uma síntese mental em que percebemos os significados do cinema - expresso pelo rolo de filme e o poeta como algo que não passa no tempo e que buscam a comunicação de formas diferentes, implicitamente 
marcados pela atemporalidade dos signos. Analisaremos a terceira e última capa de livro a qual se refere ao terceiro ano do ensino médio (Figura 5).

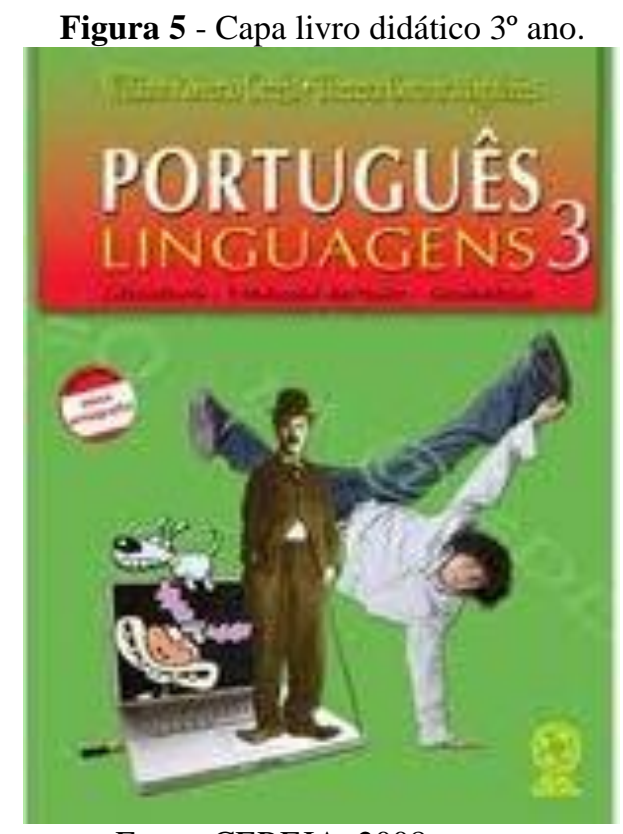

Fonte: CEREJA, 2008c.

Considerando, portanto, a composição dos elementos visuais contido na capa do livro didático, Português Linguagens 3, observamos um garoto dançando Rip Rop atrás da figura do Charlie Chaplin, a imagem do computador e nele contendo a figura de um palhaço e em cima da máquina um cachorro.

A primeiridade se refere ao imediato sem comparações ou análise, em outras palavras: é ver os fenômenos de maneira espontânea. Por isso, a primeira impressão que temos, ao olharmos a capa, é de contraste entre o presente e o passado promovida pelas imagens do rapaz dançando e do notebook que nos oferece a descrição do presente, atual. Enquanto a figura do Charlie Chaplin, relacionamos com o passado em função de ser o cinema mudo.

Já na secundidade, as reações emocionais diante do objeto observado estabelecem em nossa mente detalhes não vistos na primeiridade, como podemos observar, a figura de Carlitos, imortal criação de Charlie Chaplin, cuja imagem diz muito mais do que se poderia externalizar com palavras, seus trejeitos e interpretações encantaram plateias na época do cinema mudo, as mensagens do artista eram transmitidas por expressões sem o uso da palavra.

Observamos também um notebook, uma forma moderna de comunicação que ao mesmo tempo leva ao mundo emoções, diversões e informações. Assim como o celular, o computador virou peça necessária na vida das pessoas; a internet é algo importante para a nossa conexão com o mundo. Na tela do computador, vemos uma animação, um palhaço, cuja imagem 
remete-nos à alegria e ao divertimento, que a tecnologia pode trazer para quem possui o computador. Em seguida, notamos sobre a tela do computador um pequeno cão, que possivelmente transmite a ideia de segurança que podemos ter quando buscamos informações. Observamos também um adolescente dançando Rip Rop, a dança possui uma linguagem própria. Sua batida forte e rápida propõe uma comunicação entre o movimento e o ritmo com seus ouvintes. A música revela situações comuns do dia-a-dia e as desigualdades sociais e culturais.

Importante salientar ainda, que as três cores escolhidas para estampar as capas dos livros: verde, laranja e azul servem para diferenciar as obras, bem como contribuem para compor o painel que remete ao diálogo entre linguagens. A terceiridade busca na primeiridade e secundidade informações sobre o requerido objeto. O processo da mediação nos possibilita interpretarmos o que vemos. Ao olharmos para a figura de Charlie Chaplin - ícone de sucesso no cinema, por exemplo, automaticamente associamos esse personagem à figura de um artista aclamado e consagrado no cinema. Ele criou um dos personagens mais conhecido na história cinematográfica.

Quanto ao notebook, temos quase uma regra, de que é um objeto o qual não podemos deixar de ter, é um símbolo de modernidade, de estar informado, atualizado, etc. A dança do Rip Rop nos remete à liberdade sem limites e, por vezes, à violência e ao vandalismo. Percebemos, na terceiridade, que há uma conexão dos signos, que tais imagens são vinculadas entre si, ou seja, ontem ou hoje, de maneiras diferentes elas são utilizadas para materializar a comunicação entre as pessoas.

\section{ANÁLISE COMPARATIVA}

Em suma, as capas analisadas têm como principal propósito apresentar como a comunicação se dava no passado e Dar-se-á hoje. A coleção Português Linguagens, como a própria capa sugere, adota uma abordagem que rompe os limites estritos da palavra e procura levar para a sala de aula a interação da linguagem literária com outras linguagens: o cinema, o teatro, a pintura, os quadrinhos, o cartum, a música, a dança, a fotografia, entre outros. As imagens contidas na capa dos livros compõem o painel que remete ao diálogo entre linguagens e permite ao aluno vislumbrar a arte, a música, a literatura do passado como parte da nossa história.

É notório que a literatura ocupa um lugar de destaque na coleção, conforme sugerem as capas, bem como se observa a preocupação de desvincular o aluno da ideia de que a 
linguagem literária é algo do passado, quando colocam lado-a-lado "veículos" de comunicação da atualidade. Dessa maneira a capa demonstra aos alunos que, assim como a linguagem atual, fornecida pelas inovações tecnológicas, também estabelecem comunicação entre os indivíduos, a arte, o cinema, teatro, pintura, além de estreitar a comunicação de forma atemporal.

Outro ponto em comum encontrado nas três capas é a posição em que estão organizadas as palavras literatura, produção de texto e gramática ocorrida no alto das capas. Possivelmente esta ordem nos sugere o que vem sendo debatido na educação: que o processo de aprendizagem da língua materna deve partir do texto, seja literário ou não, formal ou informal, oral ou escrito. Nesse sentido, acredita-se que, assim como a coleção busca estabelecer a comunicação entre as linguagens, ela também propaga a desvinculação de um ensino focado na gramática tradicional, isto é, busca com a coleção uma construção de sentido no aprendizado do aluno de forma dialógica, valorizando o seu conhecimento de mundo.

\section{CONCLUSÕES}

Considerando os conceitos da teoria Semiótica de Charles Peirce, buscamos descrever por meio do processo de significação, os elementos percebidos nas imagens em estudo. As figuras apresentadas nas três capas dos $1^{\circ}, 2^{\circ}$ e $3^{\circ}$ anos do Ensino Médio da coleção Português Linguagens, indicada pelo MEC - Ministério da Educação no Programa Nacional do Livro Didático (PNLD) - forneceu-nos a descrição de seu propósito inicial: a comunicação entre os diferentes tipos de linguagem.

Em suma, as capas analisadas têm como principal propósito apresentar como a comunicação se dava no passado e se dá hoje. A coleção Português Linguagens, como a própria capa sugere, adota uma abordagem que rompe os limites estritos da palavra e procura levar para a sala de aula a interação da linguagem literária com outras linguagens: o cinema, o teatro, a pintura, os quadrinhos, o cartum, a música, a dança, a fotografia, entre outros. As imagens contidas na capa dos livros compõem o painel que remete ao diálogo entre linguagens e permite ao aluno vislumbrar a arte, a música, a literatura do passado como parte da nossa história.

Ao fazer a análise comparativa, considerando a terceiridade, pois nela está pressuposta a primeira e secundidade, podemos verificar a articulação que há entre as três capas, as quais têm o objetivo maior de apresentar a comunicação de ontem e de hoje e como elas são atemporais.

Do ponto de vista semiótico, compreendemos que, em se tratando da categoria fenomenológica da terceiridade, o que foi posto, na primeiridade e na secundidade, permitiu- 
nos a construção dos significados, o resultado final daquilo que observamos. Esta última categoria foi responsável, então, pela definição do signo, capaz de gerar, produzir o significado do signo apresentado.

Por fim, dada a importância dessas categorias universais e, também, com o propósito de confirmar que, embora a Semiótica de Peirce seja uma ciência não aplicável, ela contribui como método de análise, neste estudo, a não verbal, conforme Dias (2013). A Semiótica Peirceana é, portanto, utilizada como método de investigação científica de outras ciências, uma vez que nada pode ser investigado sem signos contribuíram Morris (1976), Fidalgo (1998) e Santaella $(1983 ; 2000 ; 2002)$.

\section{REFERÊNCIAS}

CARONTINI, E.; PERAYA, D. O projeto semiótico: elementos de semiótica geral. Tradução de Alceu Dias Lima. São Paulo: Cultrix, 1979.

CEREJA, R. W.; MAGALHÃES, C. T. Português linguagens 1. 6. Ed. São Paulo: Ed. Saraiva, 2008a.

CEREJA, R. W. Português linguagens 2. 1. ed. São Paulo: Ed. Saraiva, 2008b.

CEREJA, R. W. Português linguagens 3. 6. ed. São Paulo: Ed. Saraiva, 2008c.

DIAS. A. T. B. B. B. Semiótica Peirceana: método de análise em pesquisa qualitativa. Revista Indagatio Didactica, v. 5, n. 2, p. 884-895, 2013.

ECO, U. Semiótica e filosofia da linguagem. São Paulo: Ática, 1991.

EPSTEIN, I. O signo. 4. ed. São Paulo: Ática, 1991.

FIDALGO, A. Semiótica: a lógica da comunicação. Covilhã: Universidade da Beira Interior, 1998. Disponível em: <http://www.bocc.ubi.pt/pag/_texto.php3?html2=fidalgo-antonio-logicacomunicacao.html>. Acesso em: 10 de out. 2012.

MARTINS, A. L. P.; SIMÕES D.; FREITAS, M. N. F. (Org.). Diálogos intersemióticos II. Rio de Janeiro: Dialogarts, 2011. Disponível em:

$\langle$ http://www.dialogarts.uerj.br/arquivos/coloquio_dialogos_intersemioticos_2.pdf $\rangle$. Acesso em: $15 \mathrm{de}$ out. de 2012.

MERRELL. F. A semiótica de Charles S. Peirce hoje. Ijuí: Ed. Ijuí, 2012.

MORRIS W. C. Fundamentos da teoria dos signos. Tradução: Paulo Alcoforado e Milton José Pinto e Nicolau Salum. Rio de Janeiro: Eldorado, 1976.

NETTO, J. T. C. Semiótica, informação e comunicação: diagrama da teoria do signo. 3. ed. São Paulo: Perspectiva, 2003. 
NICOLAU, M. et al. Comunicação e semiótica: visão geral e introdutória à Semiótica de Peirce. Revista Eletrônica Temática, v. 6, n 08, ago. 2010. Disponível em: <www.insite.pro.br/2010/Agosto/semiotica_peirce_nicolau.pdf>. Acesso em 24 de out. de 2012.

PEIRCE, C. S. Semiótica. Tradução de José Teixeira Coelho Neto. 3. ed. São Paulo: Perspectiva, 2000. $337 \mathrm{p}$.

SANTAELLA, L. O que é semiótica. São Paulo: Brasiliense, 1983.

SANTAELLA, L. O que é semiótica. São Paulo: Brasiliense, 1989.

SANTAELLA, L. A teoria geral dos signos. São Paulo: Pioneira, 2000.

SANTAELLA, L. Semiótica aplicada. São Paulo: Cengage Learning, 2002.

SANTAELLA, L. Matrizes da linguagem e pensamento: sonora, visual, verbal: aplicações na hipermídia. São Paulo: Iluminuras; FAPESC, 2006.

SIMÕES, Darcilia M. P. Semiótica na comunicação lingüística: um instrumental indispensável. In: FÓRUM DE ESTUDOS LINGUÍSTICOS DA UERJ, 5., 2001, Rio de Janeiro. Comunicação em mesa-redonda. Rio de Janeiro: Uerj, 2001. p. 1 - 12.

WALTHER-BENSE, Elisabeth. A teoria geral dos signos: introdução aos fundamentos da semiótica. São Paulo: Perspectiva, 2000.

Recebido em: 30/09/2014

Aceito em: 30/09/2014

Publicado em: 10/12/2014 